\title{
Compensating Executives Based on Performance
}

\author{
Mohammed R. Ahmed ${ }^{1}$ \\ ${ }^{1}$ Huizenga College of Business, Nova Southeastern University, Ft. Lauderdale, Florida, USA \\ Correspondence: Mohammed R. Ahmed, Huizenga College of Business, Nova Southeastern University, Ft. \\ Lauderdale, Florida, USA.
}

Received: October 3, 2016

Accepted: October 17, $2016 \quad$ Online Published: November 2, 2016

doi:10.5430/ijba.v7n6p1

URL: http://dx.doi.org/10.5430/ijba.v7n6p1

\begin{abstract}
The question of fair executive compensation could be resolved if we develop a framework and measures to determine whether executives are compensated fairly by firms. Executive compensation is a business decision, and it should be based on business performance. This paper presents tools for investors and analysts for analyzing executive compensation, and provides for the board of directors a framework for developing a fair executive compensation policy. The model for executive compensation includes four variables: culture, governance, disclosure, and oversight, for creating an environment for the board of directors to evaluate and formulate a fair compensation policy. The model includes two measures: (1) an executive compensation ratio-a measure for comparing executive compensation to the value created for the firm during a period of time and (2) a comparative compensation ratio-a measure for comparing executive compensation with employee compensation. The researcher recommends that the management share these measures with the public in both quarterly and annual reports.
\end{abstract}

Keywords: executive compensation, compensation model, corporate governance, full disclosure

\section{Introduction}

Businesses are creative in solving customer problems, satisfying the wants and needs of the customer, and competing fiercely in the marketplace to capture market share. Corporate teams are working hard to train employees to be creative and innovative to generate value for the customer and the shareholders. At the same time, corporations are creatively allocating a large amount of benefits for the top executives from the wealth generated from the stockholder capital, borrowed capital on behalf of the stockholder, and the creative human capital invested by the employees (Ahmed, 2010). Corporations have ignored fair compensation policies for executives and upper level management with the argument that over-compensation is necessary to attract experienced and knowledgeable managers. The problem with this traditional argument is that it ignores the fact that corporations create value through a team of employees, a board of directors, managers, executives, suppliers, lenders, stockholders, and other stakeholders. The corporate executive compensation is a business decision, and the decision should be based on business performance. The goal of this paper is to develop a fair compensation model for corporate executives based on business performance.

A review of the management practices of Enron, WorldCom, Tyson, AIG, and troubled finical service firms suggests that they had a strong desire to satisfy their Individul wants and needs and used this to climb their hierarchy of needs (Ahmed, 2010). The management in these companies should have focused on collective needs rather than on individual needs. Passion and compassion are needed in corporate management to generate value for the stockholders, not just to fulfill the individual needs and wants of the executive management. These are needed for generating wealth for the stockholders and protecting the interests of lenders, suppliers, customers, and other stakeholders. The board of directors has the responsibility to oversee the compensation policy for the executives in a given corporation. In general, the board has ignored the idea of compensation related to performance and has used the argument that the compensation demanded by the executives is necessary to attract experienced and knowledgeable managers (Ahmed, 2014). The problem with this much-used argument is that it ignores the fact that corporate value is created by a team, and not by the sole effort of the executive management. In the past, corporate boards and management were able to justify and keep the corporate compensations of executive and upper level management out of the public eye. The financial crisis of the financial services and automobile industries and the subsequent government bailout of financial institutions and the auto industry have brought corporate executive compensation policies into the public domain because of taxpayers' investment in the bailout. 
The corporate executive compensation policy should be of concern to the shareholders because executives are compensated from their income and wealth. An average investor (shareholder) is not aware of the portion of the current income, and future wealth is being shared as executive compensation. This lack of knowledge may contribute to the fact that (1) the compensation includes salaries, bonuses, loans, stock options, and other designed benefits for the executives, and (2) the information about the compensation is not presented to the shareholders in a simple and clear fashion. The goal of this paper is to present a model for executive compensation, and provide simple measures that average investors will be able to use to determine the income and value shared as executive compensation. The scope of this paper is limited to a framework and measures for evaluating executive compensation in relation to the performance of the executive in creating the value of the firm. Furthermore, the model presented in this paper could be used in formulating a fair executive compensation policy of the company.

\section{Literature Review}

Corporate executive compensation has been a topic of discussion over the last few decades in the academic research community. Researchers were focused on increasing executive salaries and the relationship between the executive pay and company size and profits (Roberts, 1956; Baumol, 1959; Lewellen \& Huntsman, 1970; Ciscel \& Carroll, 1980; Rosen, 1992). The growth in investment vehicles such as mutual funds, pension funds, and individual investor's participation in the stock market direct the focus on understanding the relationship between executive compensation and company performance (Coughlan \& Schmidt, 1985; Murphy, 1985; Jensen \& Murphy, 1990). As the shareholders', regulators', and investment mangers' interest grew regarding executive compensation, researchers focused on the relationship between compensation and performance in relation to the industry or market (Antle \& Smith, 1986; Gibbons \& Murphy, 1990; Xu \& Han, 2013; Coville, 2013; Lassoued \& Elmir, 2012). Executive compensation is of concern to global investors and managers, and that is why researchers have focused on executive compensation practices in the U.S., Europe, and Asia (Conyon, Gregg, \& Machin, 1995; Cosh \& Hughes, 1997; Kato \& Rockel, 1992; Kato, 1997; Kaplan, 1997; Zhou, 1999; Angel \& Fumás, 1997; Brunello, Graziano, \& Parigi, 1999; Groves, Hong, McMillan, \& Naughton, 1995; Jeong \& Kim, 2013). Most of the research in the past has focused on understanding the relationship between executive compensation and performance. The focus of this research is to present a framework for developing a fair executive compensation policy and measuring the relationship between executive compensation and performance.

Executive compensation is a business decision, and business decisions should be based on business performance. The board of directors has the responsibility to protect the interests of the stockholders. The financial crises in the financial services industry revealed that the stockholders' interests are not being protected. There is a need for a model that will protect the financial interests of the stockholders and, at the same time, provide a fair corporate compensation for executives. There are several measures available to investors, analysts, and researchers for analyzing a company's financial performance. The five widely used measures are liquidity, leverage or debt management, activity or asset management, profitability, and market or earnings. The investors use the five sets of ratios to determine the financial performance of the company and to make informed investment decisions. These ratios reveal information about the company's liquidity, labor and material costs, asset efficiency, debt position, profitability, market value, and the dividends paid to shareholders. There is no one simple measure or one ratio to evaluate the executive compensation in relation to the value created during a particular period. The shareholders are the owners of the company, and they have a right to know the compensation paid to its agents who are managing the company on behalf of the shareholders. The shareholders need a simple ratio (measure) that shows the relationship between executive compensation and the total value created during a given period. The review of the literature shows that there is no simple measure available for average shareholders to determine the relationship between the executive compensation, and the value created for the organization during a given period. To fill the gap in the literature and provide a simple measure for executive compensation, the following executive compensation model was developed.

\section{Executive Compensation Model}

The proposed model includes four variables that are needed to create an environment where a fair compensation plan for the executive can be developed, implemented, and monitored. The four variables are: 1) culture, 2) governance, 3) disclosure, and 4) oversight. Once the corporate framework is designed based on these four variables, the next step is to develop a measure to compensate executives based on the overall performance of the company. Company performance is measured by the increase in the value of the firm. The increase in the value of the firm results from a company's ability to generate future cash flows for the company. The future cash flows depend on growth in revenues and reduction in operational and financial costs. The model includes variables such as revenues, costs, cost 
of capital, earnings, return on equity, and the value of the firm for determining the performance of the management. Based on the management's performance, a ratio between the performance and the compensation of the executive management is calculated. The performance of the firm is the combined effort of both management and employees, and that is why a ratio between executive compensation and employee compensation is also calculated. The goal of the model is to (1) share all the executive compensation information with the shareholders in a simple and clear fashion, (2) explain how the company is compensating their executives in relation to the value created for the company, and (3) show how executives are being compensated compared to employees. The five steps in determining executive compensation are as follows:

1. Calculate the value created by the management.

2. Determine the total compensation paid to the executives.

3. Calculate the ratio between the values created and total compensation.

4. Calculate the total employee compensation.

5. Calculate the ratio between employee and executive compensation.

Below is the model for determining executive compensation based on business performance.

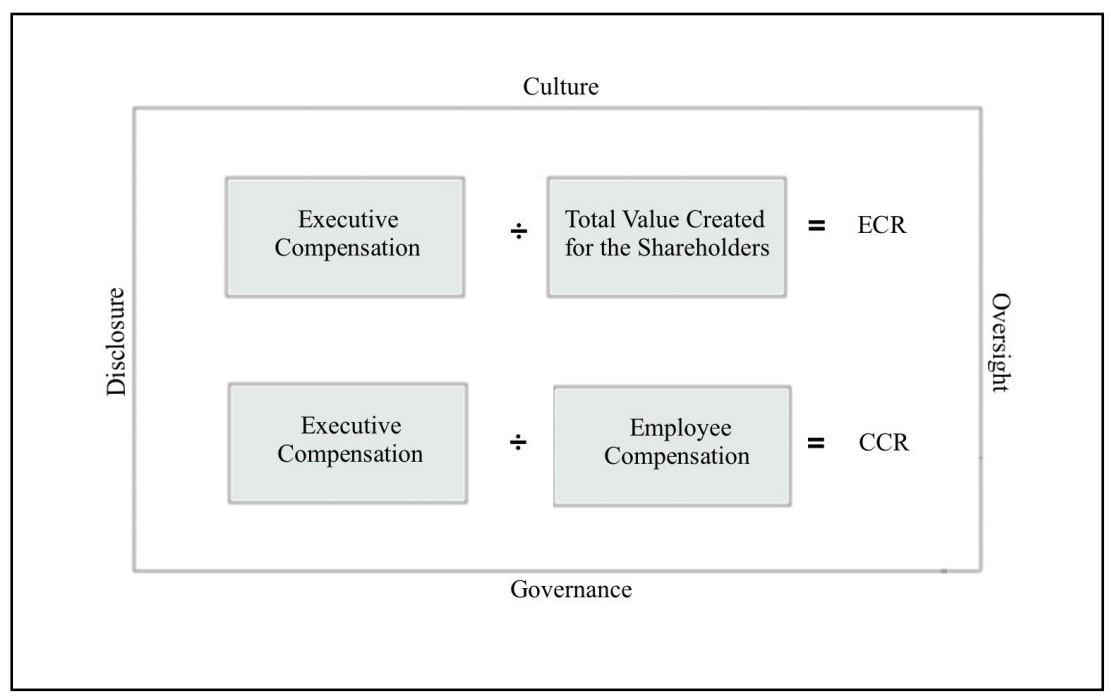

Figure 1. Executive compensation model

\subsection{Corporate Culture}

Culture is defined as the values, beliefs, and rituals of a group or organization. In an organization, the culture is influenced by the national culture, regional culture, and the personal culture of the management and employees. Corporations are in business to make money, and to make money, the management has recognized the importance of corporate culture in implementing the corporate strategy, focused on developing culture that will benefit the company. The responsibility of developing the corporate culture lies in the hands of the executive management. The executive management promotes teamwork, innovation, creativity, customer focus, community service, and other values and beliefs necessary for the survival of the company in the marketplace. The executive management's efforts sometimes result in a productive culture and sometimes in a less productive culture. The problem with both productive and less productive corporate culture is that there is a split in the culture based on the hierarchy of the organization. The split in corporate culture may be the result of the personal greed of the executive management. The members of the executive management, because of their position in the corporate hierarchy, believe that their benefits and compensation plans must be separate from those of the corporate team (employees). This split in culture arises whenever a team, community, organization, or country promotes unity for accomplishing a goal, and the rewards of the accomplishment are not shared in an equitable fashion. Such corporate compensation policy will not change unless the culture of greed is changed into a culture of passion and compassion for collective benefits in the organization. It is the board of directors' responsibility to introduce a culture of passion and compassion by hiring an 
executive team that believes in the concept that the corporate team creates corporate value and the rewards should be shared by the team in a fair manner. This leads to the question of whether the board of directors is performing its fiduciary duties and protecting the interest of the stockholders and all stakeholders.

\subsection{Corporate Governance}

The stockholders elect the board of directors and it is the board's fiduciary duty to oversee the interest of the stockholders. The problem with the corporate board is that most of the board members are not independent thinkers and decision makers. If they were independent thinkers and decision makers, we would not have faced the financial crises in the auto industry, financial services industry, and the bankruptcies of several companies in U.S. The financial crises suggest that boards of directors are influenced by the management and are not participating in the corporate governance process. The first step in improving the board of directors' fiduciary role in a corporation is to streamline the board of directors' selection process. The board of directors must have business education, be familiar with the business and industry, and be involved in continuing professional development. In this rapidly changing economic and technological environment, it is important that the board of directors has the necessary knowledge and skills to make decisions that are in best interest of the stockholders and stakeholders. Second, there should be a limit to how many companies' boards a member can participate in at one time. Allowing the directors of the board to sit on multiple boards makes them part-time participants and limits their involvement in the management, keeps them out of the individual corporate culture, and may raise the question of conflict of interest. Third, compensation for the board of directors should be based on the performance of the company - this means a small amount of annual compensation plus stock compensation based on the long-term performance of the company. Performance-based compensation for the board of directors will force the board to be more involved in its fiduciary duties and make decisions that will create value for the stockholders. Moreover, performance based compensation will make the board of directors think more independently, and because of their personal benefits board of directors may develop a fair compensation package for the executive management. Once we have addressed the fiduciary role of the board of directors in the corporation, we then are able to focus on management compensation. To make sure the board of directors meets the education, experience, and professional and development requirements, the corporation must disclose all the information about the board of directors in a clear, simple, and timely manner to the public. This disclosure will help the stockholders in making an investment decision and the market in determining the fair value of the security.

\subsection{Corporate Disclousre}

In an efficient market, all available information is rapidly digested to reflect the fair value of the security. If the executive compensation information is not fully disclosed by the management, the value of the security in the market is not the fair value of the security. In the current disclosure format, management compensation information is not disclosed fully and in a simple and clear fashion, and it is difficult for the average investor to find the executive compensation information and determine the impact on the value of the firm. The information that needs to be disclosed by the company to the shareholders and lenders includes the salaries, cash bounces, stock options, loans and loan forgiveness, compensation for early departure, and any other designed compensation. There should be a standard for reporting this information by all the companies listed on the stock exchange. For example, on the last page of the annual report, the firm should list all compensation and benefits received by the executive management and the value created by the company during the same period. In simple terms, the last page of every annual report should show the value created and the amount compensated for creating that value. This information is essential for valuing the security and for making informed investment decisions. This disclosure requirement could be implemented voluntarily by publicly held corporations, as an exchange listing requirement, or under SEC requirements. The goal of this disclosure should be to provide accurate and timely information to the public to improve market efficiency and allow for good investment decisions.

\subsection{Corporate Oversight}

After the great stock market crash of 1929 and the great depression of 1930s, Congress created the Security and Exchange Commission (SEC). The goal was to create investor confidence in the stock market and to disclose all available information to the public. According to the SEC, the mission is to protect investors; maintain fair, orderly, and efficient markets; and facilitate capital formation. To protect investors and maintain efficient markets, the SEC should make sure the all information about the company, including executive compensation, is disclosed by the company in a simple and clear fashion to the public. A full and clear disclosure of the compensation is needed to maintain an efficient market. The stockholders are the owners of the company, and it is their money that is being used to generate profits. The stockholders have a right to this information in a simple and clear fashion. The 
company needs to publish each quarter as well as annually how much in salaries and bonuses were paid to the executives. Moreover, the company should present the relationship between the corporate compensation of the executives and the wealth created by the company for the stockholders during the same period. The SEC should require all corporations to present quarterly and yearly pie charts of revenues showing the breakdown of revenues, costs, expenses, and profits; a bar graph of value created during the period; and the ratio of executive compensation compared to value created during the period as well as the return on equity for the period. The period could be quarterly or annually based on the filling and sharing requirements. The revenue, cost, expenses, and profit pie chart should show how well the company managed costs and generated profits. The value creation bar chart should indicate the change in the value of the stock during the period. The executive compensation ratio chart should show the portion of value created during the period and how it was shared with the executive management. This information, when presented in a simple and clear fashion, will help investors in making investment decisions and in maintaining efficient markets. The SEC should require the companies to present this information inside the font page or back page of the quarterly or annual reports. In addition, the SEC needs to work closely with accounting standards boards to make sure there are no accounting loopholes to distort the executive compensation disclosure. In simple terms, there should be no laws or accounting or non-accounting rules that allow management to hide executive compensation from the public.

This paper presents a compensation model for executive compensation based on business performance. Corporate compensation is a business decision, executive compensation must be related to business performance, and the company should disclose the total compensation in relation to the value created during the period. The two measures or indicators developed in this study to monitor the executive compensation of the executive management are:

\section{Executive Compensation Ratio (ECR)}

\section{Comparative Compensation Ratio (CCR)}

Both ECR and CCR ratios are calculated according to the following the five steps: 1) calculate the value created by the management, 2) determine the total compensation paid to the executives, 3) calculate the ratio between the values created and the total compensation, 4) calculate the total employee compensation, and 5) calculate the ratio between employee and executive compensation.

The value of the organization is determined in the marketplace by the market price of the stock. The stock price is a reflection of the future cash flows of the company. The market price of stock may or may not reflect the actual value created by the management. To determine the value created during a period for the firm, an average of the fair value and market value of the company is calculated to determine the value of the company in the model. The value created by the management during the year is the difference between the value of the current year and the previous year. The total compensation paid to the executives includes the salaries, bonuses, stock options, loans, loan forgiveness, and other benefits during a period. The first ratio, executive compensation to performance ratios, is the relationship between total executive compensation and total value created during a given period. It shows the executive compensation as a percentage of the total value created during a given period of time. As a simple example, the executive compensation is $\$ 30$ and the value created during the period is $\$ 100$. The executive compensation to employee compensation ratio is thus 30 percent. The executives are compensated 30 percent of the value created during the period. The executive compensation to performance ratio is calculated as follows:

$\mathrm{ECR}=$ (total executive compensation / total value created during the year)

The second ratio is the relationship between the total executive compensation and the total employees' compensation. It shows the average executive compensation as a multiple of the average employee compensation. For example, if the average executive compensation is $\$ 100$ and the average employee compensation is $\$ 10$, the executive compensation to employee compensation ratio is 10 times. The executives are compensated 10 times compared to the average employee compensation. The total employee compensation includes salaries, wages, bonuses, and benefits. The executive compensation to employee compensation ratio is calculated as follows:

$$
\mathrm{CCR}=\text { (total executive compensation / total employee compensation) }
$$

The two ratios show how executives and employee are being compensated, and the value created for the shareholder during a given period. The ratios show information on the relationships between the variables that are important for shareholders in making good investment decisions. The measure of the ratios such as percentages, and number of times are simple measures for sharing executive compensation information with the shareholders. 


\section{Results}

To develop an executive compensation ratio, we need compensation data and information from the management. The question is whether the information on executive compensation for a given period is readily and publicly available to investors or is provided by management. To find an answer to this question, a sample of 10 groups from MBA finance classes was selected. The finance classes were selected because the learners will be exposed to the individual and composite corporate financial data, market data, industry data, and the corporate compensation. Most of the learners in the finance classes were working adults from diversified functional areas of business. In the finance courses, one of the assignments was to analyze a publicly held corporation (a normal course assignment in the finance courses), and each group must present their findings to the potential or existing shareholders at the end of the term. The company analysis included a three-year financial statements analysis, a ratio analysis, financial forecasting, a cost of capital analysis, a bankruptcy analysis, an industry analysis, products and services, and the valuation of the company. Furthermore, the group was supposed to be prepared to answer any questions raised by the existing or potential stockholders.

At the end of the presentation during the questions and answers period, the 20 selected groups were asked the following 5 questions regarding executive compensation: (1) Do you know the executive compensation for the current year? (2) What is included in the executive compensation? (3) Was it easy to find the executive compensation data for the company? (4) Do you invest in the stock market? (5) Is the compensation to value created ratio that shows the relationship between the total executive compensation and the total value created in the same period a good measure for the executive compensation?

The 20 groups from the MBA courses were selected because they represent average investors who work 5 days a week and participate in the stock market to support children's education or to plan for their retirement. They will have access to all of the financial databases in the library to find the needed information for the company analysis and answer the questions on executive compensation. Furthermore, the group work brings synergy to the knowledge of the group. The following is the summary of the responses to the question 1.

Table 1. Do you know the total executive compensation for the current year?

\begin{tabular}{lllll}
\hline \multirow{2}{*}{ Question } & \multicolumn{2}{l}{ Response } & & \\
\cline { 2 - 5 } & Yes & Percentage & No & Percentage \\
\hline 1 & 80 & 95.2 & 4 & 4.8 \\
\hline
\end{tabular}

The analysis of the answers for the question 1 from the 10 groups shows that $95.2 \%$ of the group members believed that they had all of the information on executive compensation. The following is the summary of the responses to the question 2.

Table 2. What is included in the executive compensation?

\begin{tabular}{llllll}
\hline \multirow{2}{*}{ Question } & Response & & & \\
\cline { 2 - 6 } & Salaries & Bonuses & Options & Loans & Other \\
\hline 2 & 84 & 76 & 50 & 20 & 10 \\
\hline
\end{tabular}

Once they were asked about the specific types of compensation, such as bonuses, options, and loan payoffs, they realized that they did not have all of the information of the total executive compensation. The following is the summary of the responses to the question 3 . 
Table 3. Is the executive compensation data easy to find?

\begin{tabular}{|c|c|c|c|c|}
\hline \multirow[b]{2}{*}{ Question } & \multicolumn{4}{|c|}{ Response } \\
\hline & Yes & Percentage & No & Percentage \\
\hline 3 & 24 & 28.6 & 60 & 71.4 \\
\hline
\end{tabular}

After becoming familiar with all of the variables involved in calculating the total executive compensation, $71.4 \%$ indicated that it was hard to find the data for computing the total executive compensation. The following is the summary of the responses to the question 4 .

Table 4. Do you invest in the stock market?

\begin{tabular}{lllll}
\hline \multirow{2}{*}{ Question } & \multicolumn{2}{l}{ Response } & & \\
\cline { 2 - 5 } & Yes & Percentage & No & Percentage \\
\hline 4 & 64 & 76.2 & 20 & 23.8 \\
\hline
\end{tabular}

The groups consisted of working adult learners, with $76.2 \%$ actively involved in directly or indirectly investing in the stock market through their companies. The following is the summary of the responses to the question 5 .

Table 5. Is the compensation to value ratio a good measure of executive compensation?

\begin{tabular}{lllll}
\hline \multirow{2}{*}{ Question } & \multicolumn{2}{l}{ Response } & & \\
\cline { 2 - 5 } & Yes & Percentage & No & Percentage \\
\hline 5 & 82 & 97.6 & 2 & 2.4 \\
\hline
\end{tabular}

Although $76.2 \%$ of the group members were actively involved in the stock market, $97.6 \%$ of the group members believed that a ratio of executive compensation to total value created during a period is a good measure for evaluating the executive compensation.

The analysis of the data shows that the average investors are not familiar with all of the variables involved in the total executive compensation. The data are not readily available to the investors, there is no simple measure for evaluating the compensation paid to the executives, and there is a need for a simple ratio for executive compensation, such as liquidity, leverage, asset management, debt management, or profitability ratios. The goal of this paper is to develop a model for executive compensation that includes a framework and a ratio (measure) for determining the relationship between compensation and value created during a given period. The survey of 20 groups of MBA learners suggests that there is a need for a simple measure for determining the corporate compensation ratio.

\section{Discussion}

The stockholders are the owners of the company, the managers are the agents, and the employees produce the products or services for customers to generate profits and long-term value for the company based on the goals set and strategies formulated by the top-level management. The goal of this paper was to develop a fair compensation model for corporate executives based on business performance. To develop a fair compensation model, it was important to establish the fact that the shareholders are the owners of the company, the managers are the agents of the shareholders, and both executives and employees create the value. The shareholders as the owners take all the investment risks, and management do not take any investment risks. The shareholders as owners have a right to periodically learn how the executives are being compensated in a simple and clear fashion. The simple ECR measure presented in the paper clearly shows how much value has been created during a given period and how much has been shared as compensation to the executives. As owners of the company, shareholders are also interested in learning the relationship between executive compensation and employee compensation because both the management and the 
employees create the value for the shareholders. The second simple measure presented in the paper, CCR, clearly shows the gap between executive compensation and employee compensation.

To implement a fair executive compensation policy, the company has to create an environment by focusing on the four variables of 1) culture, 2) governance, 3) disclosure, and 4) oversight. Once the corporate framework is designed based on these four variables, the next step is to use the two measures of ECR and CCR to compensate executives based on the overall performance of the company. The management has to acknowledge that the value is created by both executives and employees and that the higher the gap between executive compensation and employee compensation, the greater the chances the compensation policy is not fair. Finally, the traditional argument that overcompensation is needed to attract talented executives is not a valid argument in today's business environment. In the "old days," there was a large knowledge gap between executives and employees. As we have entered into a knowledge-based economy, the knowledge gap has narrowed, which means the difference in contributions toward creation of value is shrinking. These changes in the business environment should narrow the gap between executive compensation and employee compensation.

\section{References}

Ahmed, Mohammed R., \& Ahmed, Betty E. (2014). Compensating executives based on performance is fair compensating strategy. International Conference on Business, Hawaii, May 2014.

Ahmed, Mohammed, R. (2010). Performance-based corporate compensation model for executive compensation. International Conference for Academic Disciplines, Orlando, International Journal of Arts and Sciences, Florida. March 2010.

Angel, P., \& Fumás, V. (1997). The compensation of Spanish executives: A test of a managerial talent allocation model. International Journal of Industrial Organization, 15(4), 511-531.

Antle, R., \& Smith, A. (1986). An empirical investigation of the relative performance evaluation of corporate executives. Journal of Accounting Research, 24(1), 1-39.

Baumol, W. (1959). Business behavior, value and growth. New York.

Brunello, G., Graziano, C., \& Parigi, B. (1999). Executive compensation and firm performance in Italy (Doctoral dissertation, University of Udine).

Ciscel, D., \& Carroll, T. (1980). The determinants of executive salaries: An Econometric survey. Review of Economics and Statistics, 62(1), 7-13.

Conyon, M., Gregg, P., \& Machin, S. (1995). Taking care of business: Executive Compensation in the United Kingdom. The Economic Journal, 105, 704-714.

Cosh, A., \& Hughes, A. (1997). Executive remuneration, executive dismissal and institutional shareholdings. International Journal of Industrial Organization, 15(4), 469-492.

Coughlan, A., \& Schmidt, R. (1985). Executive compensation, management turnover, and firm performance: An empirical investigation. Journal of Accounting and Economics, 7(1-3), 43-66.

Coville, T. G. (2013). Post-Sarbanes-Oxley changes in the composition of boards: Have they impacted CEO compensation? Review of Business, 33(2), 55-66.

Gibbons, R., \& Murphy, K. J. (1990). Relative performance evaluation for chief executive officers. Industrial and Labor Relations Review, 43(3), 30s-51s.

Groves, T., Hong, Y., McMillan, J., \& Naughton, B. (1995). China's evolving managerial labor market. Journal of Political Economy, 103(4), 873-892.

Jensen, M., \& Murphy, K. J. (1990a). Performance pay and top-management incentives. Journal of Political Economy, 98(2), 225-64.

Jeong, K., \& Kim, H. (2013). Equity-based compensation to outside directors and accounting conservatism. Journal of Applied Business Research, 29(3), 885-900.

Kaplan, S. (1994). Top executive incentives in Germany, Japan, and the US: A comparison. Journal of Political Economy, 1994, 102(3), 510-46.

Kato, T. (1997). Chief Executive Compensation and Corporate Groups in Japan: New evidence from micro data. International Journal of Industrial Organization, 15(4), 493-510. 
Kato, T., \& Rockel, M. (1992). Experiences, credentials, and compensation in the Japanese and US managerial labor markets: Evidence from new micro data. Journal of the Japanese and International Economy, 6(1), 30-51.

Lassoued, N., \& Elmir, A. (2012). Portfolio selection: Does corporate governance matter? Corporate Governance: The International Journal for Effective Board Performance, 12(5).

Lewellen, W., \& Huntsman, B. (1970). Managerial pay and corporate performance. American Economic Review, 60(4), 710-20.

Murphy, K. J. (1985). Corporate performance and managerial remuneration: An empirical analysis. Journal of Accounting and Economics, 7(1-3), 11-42.

Roberts, D. (1956). A general theory of executive compensation based on statistically tested propositions. Quarterly Journal of Economics, 70(2), 270-294.

Rosen, S. (1982). Authority, control, and the distribution of earnings. The Bell Journal of Economics, 13(2), 311-323.

Xu, T., \& Han, B. (2013). Managerial incentives and corporate cash holdings. The Journal of Applied Business and Economics, 14(1), 72-85.

Zhou, X. (1999). CEO Pay, Firm Size, and Corporate Performance: Evidence from Canada. Canadian Journal of Economics, 33(1), 2000, 213-251. 